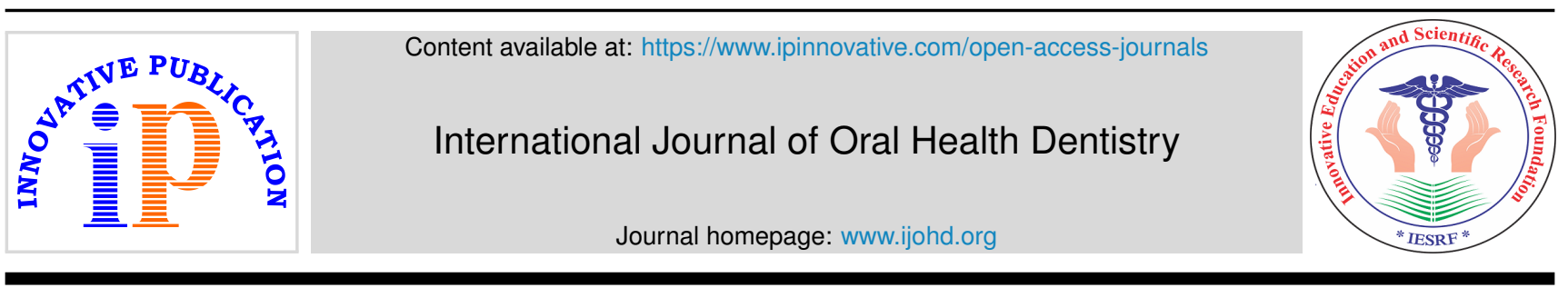

Original Research Article

\title{
A comparative clinical evaluation of the effect of chamomile, Aloe Vera and chlorhexidine $0.12 \%$ mouthwash on gingival health among visually impaired
}

\author{
Mari Nema ${ }^{1, *}$ \\ ${ }^{1}$ Dept. of Periodontology, Faculty of Dentist, Damascus University, Damascus, Syria
}

\section{A R T I C L E I N F O}

Article history:

Received 30-10-2020

Accepted 19-11-2020

Available online 02-01-2021

Keywords:

Aloe Vera

Oral health

Chamomile mouthwashes

\begin{abstract}
A B S T R A C T
Introduction: Oral health is considered of paramount importance for visually impaired individuals due to the difficulties they face to maintain a good oral hygiene practice in different aspects, knowledge, physical and social. Thus, the provision of adequate training and education about oral health and the chemical role of mouthwashes is required for this group of society. This research aims at comparing the effect of various types of mouthwashes on gingival health among visually impaired persons.

Materials and Methods: 92 students with a vision impairment of ages between (10-20) years suffering from gingivitis caused by dental plaque accumulation were included in this research. The sample was divided into 4 groups according to the type of used mouthwash as follows:

1) Chamomile group, 2) Aloe Vera group, 3) Chlorhexidine group, 4) Distilled water group.

Dental plaque index (PI) and gingival index (GI) were recorded before the initiation of the treatment and after 15 days. One-way (ANOVA test) and the (Bonferroni test) were used for results analysis at $\mathrm{p}<0.05$. Statistical analyses were completed using (SPSS) software -v13.

Results: Aloe Vera and CHX groups have improved the dental plaque index (PI) without significant statistical differences. Both (CHX and Aloe Vera) have proven superiority over the Chamomile group which was statistically significant. Gingival index (GI) has improved in the Chamomile, Aloe Vera, and CHX groups without any statistical differences.

Conclusion: Within the limitation of our study, we concluded that (Aloe Vera) mouthwashes can be used as a substitute to $\mathrm{CHX}$ in controlling plaque accumulation and gingival inflammation among visually impaired persons. Also, Chamomile mouthwashes have a distinguished impact on gingival inflammation, yet more researches are required.
\end{abstract}

(C) This is an open access article distributed under the terms of the Creative Commons Attribution License (https://creativecommons.org/licenses/by/4.0/) which permits unrestricted use, distribution, and reproduction in any medium, provided the original author and source are credited.

\section{Introduction}

Oral health is a paramount part of the overall health of each individual, ${ }^{1}$ especially those who suffer from vision problems. ${ }^{2}$ Vision impairment, known as the lack of vision or blindness, is the reduction in the ability to vision which leads to complicated problems that cannot be fixed with usual methods like glasses. ${ }^{3}$

Visually impaired individuals face an everyday challenge maintaining their oral health, which is strongly attached to their social and psychological status. ${ }^{4}$ Conventional

\footnotetext{
* Corresponding author.

E-mail address: marinema136@gmail.com (M. Nema).
}

methods of oral health care include visual images, dental plaque detectors and periodic rehearsals to the dental clinic. Unfortunately, these methods are not sufficient for visually impaired. ${ }^{5}$ The major difference between them and other individuals who are not suffering from this impairment is the difficulty in performing brushing and other routine oral health practices. Besides, visually impaired individuals cannot see the dental plaque which leads to a continuous accumulation of the dental plaque associated with gingival bleeding and periodontal pockets formation despite performing oral care instructions, ${ }^{6}$ so it is necessary to improve and facilitate these instructions for this category. ${ }^{7}$ 
The use of mouthwashes is highly recommended among visually impaired persons as an adjunctive method of controlling dental plaque accumulation. ${ }^{8}$

Chlorhexidine is an antiseptic chemical solution that belongs to the biguanides family, and it is considered to be of low toxicity. It has a wide bacterial spectrum ${ }^{9}$ that includes Gram-positive and Gram-negative bacteria, yeasts, a group of fungi strains and some viruses. ${ }^{10}$ There is a solid evidence that chlorhexidine mouthwash reduces the formation of dental plaque and gingival inflammation. ${ }^{11}$ However, it causes teeth staining, taste disorder, and other undesirable side effects. ${ }^{12}$ Moreover, recent studies have shown some bacterial resistance against $\mathrm{CHX} .{ }^{13}$

German Chamomile is one of the Asteraceae $\backslash$ Composita species plants. It consists of Kumarins, flavonoids, volatile oils, and other ingredients such as amino acids and polysaccharides. Chamomile has several significant properties such as anti-spasm, antihypertensive, analgesic, anti-inflammatory, and anti-bacterial, ${ }^{14}$ and it is used as a popular medication for treating wounds, ulcers, and burns. ${ }^{15}$ Chamomile continues to be used as one of the future medications because it contains effective vital elements that provide therapeutic effects, as Chamomile helps to improve cardiovascular conditions, stimulates the immune system, and secures some cancer prevention. ${ }^{16}$ Chamomile mouthwashes have shown a considerable decrease in both dental plaque and gingival bleeding. ${ }^{17}$

Aloe Vera plant belongs to the (Liliaceae) species. It contains more than 75 nutrients and over 200 complex compounds with biological effectiveness. ${ }^{18}$ Aloe Vera has been widely known for its many uses in cosmetics, skincare, ${ }^{19}$ and pain-relieving. ${ }^{18}$ Also, it has been applied to treat burns, rashes, skin allergies, ${ }^{20}$ treatment of rheumatoid arthritis, ${ }^{21}$ support of the immune system, and as a protection from some cancerous diseases. ${ }^{22}$ Aloe Vera has recently entered the world of dentistry for its powerful effect on bacteria and inflammation. Furthermore, the administration of Aloe Vera gel is beneficial in the treatment of aphthous ulcer and enhancing the overall periodontal status. $^{23}$

As a result of the side effects of chemical drugs and the formation of new bacterial strains that are resistant to them, searching for new natural, less toxic and less expensive materials is a hot spot nowadays. ${ }^{24}$ Thus, in our research, we have emerged interests in Aloe Vera and Chamomile and their broad uses.

\section{Materials and Methods}

A single-blind randomized clinical trial was performed to compare the effect of Chamomile, Aloe Vera and chlorhexidine mouthwashes in preventing dental plaque accumulation and gingival inflammation among visually impaired individuals.
The sample size was calculated with the ( $G$ power) program, and the study included 92-students suffering from vision impairment. Their age ranges between 1020 years, including both genders chosen from schools for the rehabilitation of the blind in Damascus city. Ethical approval was obtained from the ministry of social affairs and labor and written informed consent was acquired from the participants and their superiors.

\subsection{Preparation of the mouthwashes}

All types of mouthwashes were formulated at the department of pharmacy in Damascus university by a pharmaceutical specialist.

Chamomile mouthwashes preparation: Dried Chamomile flowers were immersed in ethanol $55 \%$ at room temperature, and impurities were removed from the mixture. Ethanol was completely evaporated at a temperature of $79^{\circ} \mathrm{C}$ by the rotary evaporator device. The pure Chamomile extract was obtained and then dissolved in distilled water, and spearmint flavor was added to the mixture.

Aloe Vera mouthwashes preparation: After washing the Aloe Vera leaves, the gel extract from the leaves was mixed with: distilled water, coconut oil, preservative material, and spearmint flavor.

All mouthwashes were kept in similar containers, and the same flavor of spearmint was added to the mixture. All containers were coded and distributed.

\subsection{Methodology}

The study was conducted for 15 days. Plaque removal and Scaling were carried out in the institute infirmary. The study participants were randomly allocated into four groups (23 persons in each group) through the lottery method, as the following:

1. Chamomile mouthwashes $2 \%$ group.

2. Aloe Vera mouthwashes group.

3. Chlorhexidine mouthwashes $0.12 \%$ group.

4. Distilled water group (control group).

Plaque index, (PI) and gingival index (GI) scores were recorded at baseline and after 15 days using the UNC-15 periodontal prop.

The instructions of oral health care maintenance, how to brush and how to use $10 \mathrm{ml}$ of the mouthwashes twice daily were explained through (touch-feel-hear) technique. Moral reinforcement and motivation were presented to ensure that the instructions are carried out, in the presence of the responsible social counselor, to provide the feeling of security and confidence. When dealing with visually impaired individuals, it is necessary to take caution not to use words that offend them. Also, patience is needed by repeating information, and allowing the visually impaired 
to touch and feel the tools to recognize them while applying the instructions.

All participants received the same type of toothbrush and toothpaste.

Inclusion criteria: All participants should have a vision impairment, plaque index score, gingival index score more than (1), and the capability to use the mouthwash without swelling.

Exclusion criteria: Individuals with history of systematic disease, the use of antibiotics, orthodontic appliances, and sensitivity to any component of the used mouthwashes.

Statistical analyses were completed using (SPSS) program software v13.

\section{Results}

A total of 92 visually impaired individuals between 10 20years participated in our study. The results of 8 participants were excluded due to the research procedures. Thus, the study sample became 84 participants, both males, and females were distributed into 4 groups according to the type of mouthwash. (Table 1)

Table 1: Distribution of the research sample according to the type of them mouthwashes

\begin{tabular}{lcc}
\hline $\begin{array}{l}\text { Percentage } \\
(\mathbf{1 0 0 \% )}\end{array}$ & Sample (n) & Type of mouthwash \\
22.6 & 19 & Chamomile \\
26.2 & 22 & Aloe vera \\
23.8 & 20 & Chlorhexidine \\
27.4 & 23 & Distilled water \\
100 & 84 & Overall \\
\hline
\end{tabular}

One-way ANOVA test was used to study the variation of change for all studied parameters (PI and GI) among the 4 groups. After 15 days, plaque index (PI) was highly improved in the CHX group $(33,73 \%)$ followed by the Aloe Vera group (33.06\%), the Chamomile group (7.15\%), and the distilled water group $(1,75 \%)$ and this was statistically significant $\mathrm{p}<0.05$.

Also, gingival index values were improved after 15 days. The highest improvement was in the Aloe Vera group (32.31\%) followed by the CHX group (31, 13\%), the Chamomile group $(29.76 \%)$, and the distilled water group $(0.53 \%)$. This was statistically significant $p<0.05$. (Table 2 )

A Bonferroni test was applied for intergroup comparison to find out which group is fundamentally different from the others considering all studied parameters.

In the plaque index: There was a significant difference $\mathrm{p}<0.05$ between groups as the following:

1. CHX group \& distilled water group

2. Aloe Vera group \& distilled water group

3. Chamomile group \& Aloe Vera group

4. Chamomile group \& $\mathrm{CHX}$ group
However, there was no significant difference $\mathrm{p}>0.05$ between the Chamomile group \& distilled water group, the CHX group \& Aloe Vera group. (Table 3)

In the gingival index: There was a significant difference $\mathrm{p}<0.05$ between groups as the following:

1. Chamomile group \& distilled water,

2. CHX group \& distilled water

3. Aloe Vera group \& distilled water group

However, there was no significant difference $\mathrm{p}>0.05$ between the Chamomile group with Aloe Vera group, Chamomile group with $\mathrm{CHX}$ group and the $\mathrm{CHX}$ group with Aloe Vera group. (Table 4)

\section{Discussion}

Visually impaired individuals, in particular, face a special challenge of maintaining good oral health since they cannot see the dental plaque accumulation. ${ }^{4}$ Therefore, brushing their teeth must be accompanied by adjunctive methods such as mouthwashes because they are easy to use. ${ }^{25}$

Chlorhexidine has achieved the best clinical outcomes in controlling dental plaque and preventing gingival inflammation. ${ }^{26}$ Nevertheless, $\mathrm{CHX}$ has many reciprocal side effects, so its long-term use is limited. ${ }^{27}$

In this context, the world health organization turned to herbal medicine for therapeutic purposes due to its low cost, ease of access and an apparent absence of side effects. ${ }^{28}$

A comparison between the effect of Chamomile, Aloe Vera, and chlorhexidine mouthwashes on gingival health among visually impaired was conducted in this research. There was a marked decline in plaque index values in both CHX group and Aloe Vera group without any significant difference. Meanwhile, the reduction was less important in the Chamomile group.

(GI) values showed a sharp reduction in the Aloe Vera group followed by $\mathrm{CHX}$ and Chamomile without any significant differences among the three groups.

Chlorhexidine is a chemical agent that is widely used to reduce dental plaque Accumulation, also used as a disinfectant or Sterilant depending on its concentration, and effective against a large group of bacteria as well as some fungi and viruses. ${ }^{29}$

In the study of (Charles in 2004) and the study of (Overholser in 1990), the decrease in plaque formation was found by $21.5 \%-50.3 \% .{ }^{30,31}$

Chlorhexidine prevents bacterial adhesion to the teeth surfaces and oral mucous membranes, and it causes damage to bacteria by increasing the permeability of the bacterial cell walls and changing the osmotic balance. Besides, it has an inhibitory effect on both Gram-negative and Yeastpositive bacteria. $^{32}$

Aloe Vera's ability to decrease the accumulation of dental plaque can be referred to its components represented by Anthraquinone which is an antibacterial 
Table 2: The results of one-way ANOVA test

\begin{tabular}{|c|c|c|c|c|c|c|}
\hline \multicolumn{7}{|c|}{ Plaque index score variation } \\
\hline $\begin{array}{l}\text { Type of } \\
\text { mouthwash }\end{array}$ & $\begin{array}{c}\text { Number of } \\
\text { participants }\end{array}$ & $\begin{array}{l}\text { Average } \\
\text { mean }\end{array}$ & $\begin{array}{c}\text { Standard } \\
\text { variation }\end{array}$ & F value & $\begin{array}{c}\text { Significance } \\
\text { level }\end{array}$ & Indication \\
\hline Chamomile & 19 & -7.15 & 8.01 & & & \\
\hline Aloe Vera & 22 & -33.06 & 14.17 & & & \\
\hline Chlorhexidine & 20 & -33.73 & 17.19 & 43.634 & 0.000 & Significant \\
\hline Distilled water & 23 & -1.75 & 2.54 & & & \\
\hline \multicolumn{7}{|c|}{ Gingival index score variation } \\
\hline $\begin{array}{l}\text { Type of } \\
\text { mouthwash }\end{array}$ & $\begin{array}{l}\text { Number of } \\
\text { participants }\end{array}$ & $\begin{array}{l}\text { Average } \\
\text { mean }\end{array}$ & $\begin{array}{c}\text { Standard } \\
\text { variation }\end{array}$ & F value & $\begin{array}{c}\text { Significance } \\
\text { level }\end{array}$ & Indication \\
\hline Chamomile & 19 & -29.76 & 13.02 & & & \\
\hline Aloe Vera & 22 & -32.31 & 14.55 & 39.643 & 0.000 & Significant \\
\hline Chlorhexidine & 20 & -31.13 & 12.59 & & & \\
\hline Distilled water & 23 & -0.53 & 1.62 & & & \\
\hline
\end{tabular}

Table 3: The results of the Bonferroni test for the plaque index score

\begin{tabular}{|c|c|c|c|c|c|}
\hline \multicolumn{6}{|c|}{ Plaque index score variation } \\
\hline \multirow[t]{2}{*}{$\begin{array}{l}\text { Type of } \\
\text { mouthwash (I) }\end{array}$} & $\begin{array}{l}\text { Type of } \\
\text { mouthwash }(J)\end{array}$ & $\begin{array}{l}\text { Difference } \\
\text { between the two } \\
\text { means } \\
(\text { I-J) }\end{array}$ & $\begin{array}{l}\text { Standard } \\
\text { variation }\end{array}$ & Significance level & Indication \\
\hline & Aloe Vera & 25.91 & 3.69 & 0.000 & significant \\
\hline \multirow[t]{2}{*}{ Chamomile } & Chx & 26.59 & 3.78 & 0.000 & significant \\
\hline & Distilled water & -5.40 & 3.66 & 0.860 & insignificant \\
\hline \multirow{2}{*}{ Aloe Vera } & $\operatorname{chx}$ & 0.68 & 3.64 & 1.000 & insignificant \\
\hline & Distilled water & -31.31 & 3.52 & 0.000 & significant \\
\hline Chlorhexidine & Distilled water & -31.99 & 3.61 & 0.000 & significant \\
\hline
\end{tabular}

Table 4: The results of the Bonferroni test for gingival index score

\begin{tabular}{llcccc}
\hline $\begin{array}{l}\text { Gingival index score variation } \\
\text { Type of } \\
\text { mouthwash }(\mathbf{I})\end{array}$ & $\begin{array}{l}\text { Type of } \\
\text { mouthwash }(\mathbf{J})\end{array}$ & $\begin{array}{c}\text { Difference } \\
\text { between the two } \\
\text { means (I-J) }\end{array}$ & $\begin{array}{c}\text { Standard } \\
\text { variation }\end{array}$ & Significance level & Indication \\
Chamomile & Aloe Vera & 2.55 & 3.60 & 1.000 & insignificant \\
& CHX & 1.36 & 3.68 & 1.000 & insignificant \\
Aloe Vera & Distilled water & -29.24 & 3.56 & 0.000 & significant \\
Chlorhexidine & CHX & -1.18 & 3.55 & 1.000 & insignificant \\
Significant & significant \\
\hline
\end{tabular}

and antifungal material. ${ }^{33}$ Moreover, Aloe Vera is distinguished by its anti-inflammation properties. It contains Carboxypeptidase which activates bradykinin. Bradykinin inhibits the production of prostaglandin resulting in reducing inflammation and pain. ${ }^{34}$ These data were consistent with (Gupta, 2014), his findings showed a similar effect of $\mathrm{CHX}$ and Aloe Vera on dental plaque Accumulation. $^{35}$ (Swathi, 2016) demonstrated in his study that Aloe Vera and CHX mouthwashes are both equally effective in lowering gingival inflammation without significant differences which confirms our results. ${ }^{36}$
(Andi Mardiana Adam 2018), studied the effect of Aloe Vera juices after scaling, and he found a decrease in the values of gingivitis from (1.2780 to 0.4113$)$, with significant differences from the control group. ${ }^{37}$

Also (Sravan Kumar Yeturu 2015), compared the effect of chlorhexidine and Aloe Vera in patients

(over 18 years of age) receiving orthodontic treatment, where gingivitis decreased by $16.30 \%$ and $9.88 \%$, respectively, and the chlorhexidine group excelled without statistical differences. ${ }^{38}$

On the other hand, the influence of Chamomile mouthwashes on the dental plaque was not as strong as $\mathrm{CHX}$ 
or Aloe Vera mouthwashes. However, it showed powerful impact on gingival inflammation. That can be interpreted by the presence of salicylic acid and flavonoids which are considered as anti-inflammatory agents. ${ }^{17}$ The results of our study were similar to Ana Luiza's 2014 which showed a reduction in gingival inflammation among patients with gingivitis and chronic periodontitis stating that both Chamomile and CHX have the same ability in preventing gingival inflammation. ${ }^{39}$ However, our results disagreed with (Paul's 2016) study which stated that Chamomile mouthwashes are as effective as CHX in controlling dental plaque among orthodontic patients aged between (1040) years. ${ }^{40}$ This variation might be because of the age differences between the two studies or the follow-up period which lasted for 30 days in Paul's study.

Our study coincided with the study of Renuka in 2017 that compared chlorhexidine rinses with herbal extracts containing Chamomile and found that despite the improvement in dental plaque index values of the in the herbal rinses group, Chlorhexidine remains the gold standard in controlling plaque. ${ }^{41}$

We also agreed with the study of (Azimi 2016) which compared the effect of Chlorhexidine mouthwashes with Chamomile in patients who had endotracheal intubation. The sample was divided into three groups: The Chlorhexidine group, the Chamomile group, and the third group that used saline, where the Chlorhexidine group outperformed in its effect on the bacteria, while there was no difference between the Chamomile group and the control group, noting that the used Chlorhexidine concentration was $0.2 \% .{ }^{42}$ Our study differed from (Pourabbas's 2010) that demonstrated the Chamomile mouthwashes ability to reduce the value of plaque index score to $22 \%$ with statistically significant differences from the control group that used Saline, while in our study we did not find significant differences between the both groups, ${ }^{17}$ and perhaps the reason for the difference is the period of using the mouthwashes which was for 30 days while in ours was limited to 15 days.

Chamomile is introduced as a standard medicinal plant due to its many therapeutic benefits. It has antibacterial, antiviral and anti-fungal effects. Besides, it contains active ingredients against Staphylococcus aureus and Candida. ${ }^{43}$

\section{Conclusion}

Within the limitation of our study, we concluded that Aloe Vera mouthwashes could be used as an alternative of $\mathrm{CHX}$ in controlling plaque accumulation and gingival inflammation among visually impaired persons. Also, Chamomile mouthwashes have a distinguished impact on gingival inflammation yet more researches are required.

\section{Source of Funding}

None.

\section{Conflict of Interest}

None.

\section{References}

1. Sheiham A. Oral health, general health, and quality of life. Bull World Health Organ. 2005;83(9):644.

2. Priyadarshini P, Pushpanjali K, Sagarkar A, Shenoy S. Assessment of oral health status among visually impaired children. J Dent Orofac Res. 2015;11(1):3-6.

3. Vashist P, Suraj SS, Gupta V, Gupta N, Kumar A. Definition of blindness under National Programme for Control of Blindness: Do we need to revise it? Indian J Ophthalmol. 2017;65:92. do1:10.4103/110.110_869_16.

4. Mahoney EK, Kumar N, Porter SR. Effect of visual impairment upon oral health care: a review. Br Dent J. 2008;204(2):63-7. doi:10.1038/bdj.2008.2

5. Prashanth ST, Das UM, Gopu H, Bhatnagar S. Oral health knowledge, practice, oral hygiene status, and dental caries prevalence among visually impaired children in Bangalore. J Indian Soc Pedod Prev Dent. 2011;29(2):102. 101-10.4103/0970-4388.84680.

6. Jain A, Gupta J, Aggarwal V, Goyal C. To evaluate the comparative status of oral health practices, oral hygiene and periodontal status amongst visually impaired and sighted students. Spec Care Dent. 2013;33(2):78-84. doi:10.1111/1.1754-4505.2012.00296.x.

7. Mohd-Dom TN, Omar R, Malik NAA, Saiman K, Rahmat N. Self-Reported Oral Hygiene Practices and Periodontal Status of Visually Impaired Adults. Glob J Health Sci. 2010;2(2):184-91. doi:10.5539/g;hs.v2n2p184.

8. Arunakul M, Asvanund Y, Tantakul A, Mitrakul K, Srisatjaluk R, Vongsavan K. Effectiveness of an oral hygiene education program combined with fluoride mouthrinse among visually impaired students in. Southeast Asian J Trop Med Public Health. 2015;46(2):354.

9. Finger TE, Danilova V, Barrows J, Bartel DL, Vigers AJ, Stone L. ATP signaling is crucial for communication from taste buds to gustatory nerves. Sci. 2005;310(5753):1495-9.

10. Salim N, Moore C, Silikas N, Satterthwaite J, Rautemaa R. Chlorhexidine is a highly effective topical broad-spectrum agent against Candida spp. Int J Antimicrob Agents. 2013;41(1):65-9. Doi:10.1016/1.1]antimicag.2012.08.014.

11. Paraskevas S. Randomized controlled clinical trials on agents used for chemical plaque control. Int J Dent Hyg. 2005;3(4):162-78. do1:10.1111/].1601-5037.2005.00145.x.

12. Ernst CP, Prockl K, Willershausen B. The effectiveness and side effects of $0.1 \%$ and $0.2 \%$ chlorhexidine mouthrinses: a clinical study. Quintessence Int. 1998;29(7):443-8.

13. Tartaglia GM, Kumar S, Fornari CD, Corti E, Connelly ST. Mouthwashes in the 21 st century: a narrative review about active molecules and effectiveness on the periodontal outcomes. Expert Opin Drug Deliv. 2017;14(8):973-82. 10i: 10.1080274252472017260178.

14. Sebai H, Jabri MA, Souli A, Rtibi K, Selmi S, Tebourbi O, et al. Antidiarrheal and antioxidant activities of chamomile (Matricaria recutita L.) decoction extract in rats. J Ethnopharmacol. 2014;152(2):327-32. do1:10.1016/].jep.2014.01.015.

15. Awang-Dennis V. The Herbs of Choice: The therapeutic use of phytomedicines. New York: Taylor and Francis Group; 2006.

16. Srivastava JK, Shankar E, Gupta S, Chamomile. Chamomile: A herbal medicine of the past with a bright future. Mol Med Rep. 2010;3(6):895-901.

17. Pourabbas R, Delazar A. The effect of German Chamomile mouthwash on dental plaque and gingival inflammation. Iran $J$ Pharma Res. 2010;p. 105-9.

18. Duke JA. Handbook of medicinal herbs. CRC press; 2002.

19. Joshi LS, Pawer HA. Herbal cosmetics and cosmeceuticals: An overview. Nat Prod Chem Res. 2015;3(2):170. 
20. Somboonwong J, Duansak N. The therapeutic efficacy and properties of topical Aloe vera in thermal burns. J Med Assoc Thailand. 2004;87:69-78.

21. Chatterjee M, Sarkar D, Dutta A, Das M, Sarkar K, Mandal C. Effect of Aloe vera on nitric oxide production by macrophages during inflammation. Indian $J$ Pharmacol. 2005;37(6):371. do1:0403/0253-76 [3.100/3.

22. Rahmani AH, Aldebasi YH, Srikar S, Khan AA, Aly SM. Aloe vera Potential candidate in health management via modulation of biological activities. Pharmacognosy Rev. 2015;9(18):120. 10i:10.4103/0973प847.162118

23. Bhat G, Dodwad V, Kudva P. Aloe vera: Nature's soothing healer to periodontal disease. J Indian Soc Periodontol. 2011;15(3):205.

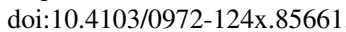

24. Heimall J, Bielory L. Defining Complementary and Alternative Medicine in Allergies and Asthma: Benefits and Risks. Clin Rev Allergy Immunol. 2004;27(2):093-104. 10:10.1385/criai:27:2:093.

25. Bugno A, Nicoletti MA, Almodóvar AA, Pereira TC, Auricchio MT. Mouthwashes: antimicrobial efficacy assessment in commercially available products. Rev does Inst Adolfo Lutz. 2006;65(1):40-5.

26. Olympio KPK, Bardal PAP, de M Bastos JR, Buzalaf MAR. Effectiveness of a chlorhexidine dentifrice in orthodontic patients: a randomized-controlled trial. J Clin Periodontol. 2006;33(6):421-6. do1:10.1111/j.1600-051x.2006.00927.x.

27. Gürgan CA, Zaim E, Bakirsoy I, Soykan E. Short-Term Side Effects of 0.2\% Alcohol-Free Chlorhexidine Mouthrinse Used as an Adjunct to Non-Surgical Periodontal Treatment: A Double-Blind Clinical Study. J Periodontol. 2006;77(3):370-84. do1:10.1902/jop.2006.050141

28. Ekor M. The growing use of herbal medicines: issues relating to adverse reactions and challenges in monitoring safety. Front Pharmacol. 2014;4:177. doi:10.3389/fphar.2013.00177

29. Karpiński T, Szkaradkiewicz A. Chlorhexidine-pharmacobiological activity and application. Eur Rev Med Pharmacol Sci. 2015;19(7):1321-6.

30. Overholser CD, Meiller TF, DePaola LG, Minah GE, Niehaus C. Comparative effects of 2 mouthrinses on the development of supragingival dental plaque and gingivitis. J Clin Periodontol. 1990;17(8):575-9. doi:10.111/j.1600-051x.1990.tb01108.x

31. Charles CH, Mostler KM, Bartels LL, Mankodi SM. Comparative antiplaque and antigingivitis effectiveness of a chlorhexidine and an essential oil mouthrinse: 6-month clinical trial. J Clin Periodontol. 2004;31(10):878-84. do1:10.1111/.1600-051x.2004.00578.X.

32. Pedreira MLG, Kusahara DM, de Carvalho W, nez SCN, Peterlini MAS. Oral Care Interventions and Oropharyngeal Colonization in Children Receiving Mechanical Ventilation. Am J Crit Care. 2009;18(4):319-28. doi:10.4037/ajcc2009121.

33. Parkar S, Janu U. Comparative evaluation of effectiveness between Aloe vera and two commercially available mouth rinses on plaque and gingival status: A randomized control trial. J Int Clin Dent Res Organ. 2011;3(1):25. ब01:10.4103/223 -(1)
34. Surjushe A, Vasani R, Saple DG. Aloe vera: A short review. Indian J Dermatol. 2008;53(4):163. 10:-10.4103/0019-5154.44785.

35. Kumar GR, Devanand G, John BD, Ankit Y, Khursheed O, Sumit M. Preliminary Antiplaque Efficacy of $<$ i $>$ Aloe Vera $</ i>$ Mouthwash on 4 Day Plaque Re -Growth Model: Randomized Control Trial. Ethiop J Health Sci. 2014;24(2):139. do1:10.4314/ejhs.v2412.6

36. Vangipuram S, Jha A, Bhashyam M. Comparative efficacy of aloe vera mouthwash and chlorhexidine on periodontal health: A randomized controlled trial. J Clin Exp Dent. 2016;8(4). doi:10.4317/jced.53033.

37. Adam AM, Achmad H, Fahruddin AM. Efficacy of Mouthwash from Aloe vera Juice after Scaling Treatment on Patient with Gingivitis: A Clinical Study. Pesquisa Bras em Odontopediatria Clín Integrada. 2018;18(1):1-6. do1:10.4034/pboc1.2018.181.32.

38. Yeturu SK, Acharya S, Urala AS, Pentapati KC. Effect of Aloe vera, chlorine dioxide, and chlorhexidine mouth rinses on plaque and gingivitis: A randomized controlled trial. J Oral Biol Craniofac Res. 2016;6(1):55-9. đoi:10.1016/j.jobcr.2015.08.008

39. Batista ALA, Lins RU, de Souza Coelho R, do N Barbosa D, Belém NM, Celestino FJA. Clinical efficacy analysis of the mouth rinsing with pomegranate and chamomile plant extracts in the gingival bleeding reduction. Complement Ther Clin Pract. 2014;20(1):93-8. d01:10.1016/].ctcp.2013.08.002.

40. Goes P, Dutra CS, Lisboa MRP, Gondim DV, Leitão R, Brito GAC, et al. Clinical efficacy of a $1 \%<\mathrm{i}>$ Matricaria chamomile $</ \mathrm{i}>\mathrm{L}$. mouthwash and $0.12 \%$ chlorhexidine for gingivitis control in patients undergoing orthodontic treatment with fixed appliances. J Oral Sci. 2016;58(4):569-74. doi:10.2334/josnusd.16-0280

41. Selvakumar R, Np M. Comparison in benefits of herbal mouthwashes with chlorhexidine mouthwash: A review. Asian J Pharm Clin Res. 2017;10(2):3. do1:10.22159/ajpcr.2017.v1012.13304.

42. Jouybari L, Azimi M, Moghadam S, Ghaemi E, Behnampoor N, Sanagoo A. Antimicrobial effects of chlorhexidine, matrica drop mouthwash (chamomile extract), and normal saline on hospitalized patients with endotracheal tubes. Iranian J Nurs Midwifery Res. 2016;21:458. 001:0.4103/135-9066. प33प0.

43. Zargaran A, Borhani-Haghighi A, Faridi P, Daneshamouz S, Kordafshari G, Mohagheghzadeh A. Potential effect and mechanism of action of topical chamomile (Matricaria chammomila L.) oil on migraine headache: A medical hypothesis. Med Hypotheses. 2014;83(5):566-9. doi:10.1016/].mehy.2014.08.023

\section{Author biography}

Mari Nema, Dentist

Cite this article: Nema M. A comparative clinical evaluation of the effect of chamomile, Aloe Vera and chlorhexidine $0.12 \%$ mouthwash on gingival health among visually impaired. Int J Oral Health Dent 2020;6(4):273-278. 